\section{SPOTLIGHT ON OPTIMISM}

\section{UN treaty would protect high seas from overexploitation. . .}

The high seas are the open ocean far from coastlines, beyond exclusive economic zones. Covering 1.5 times the total land area of the planet and home to some of the rarest and most charismatic species, this vast habitat is increasingly threatened by deep-sea mining, overfishing and the patenting of marine genetic resources. All countries have the right to navigate, fly over, research and fish on the high seas without restriction. Despite the efforts of the UN and several international groups, there currently is no overarching treaty that protects biodiversity or limits exploitation. Over the next 2 years, government representatives aim to negotiate and establish a binding agreement to protect the high seas against overexploitation. A strong global ocean treaty would allow the setting up of marine protected areas in international waters, facilitate environmental impact assessments to reduce potential harm from high-sea activities, and allow poorer countries to benefit from discoveries developed from marine genetic resources.

Source: BBC News (2018) bbc.co.uk/news/

science-environment-45397674

\section{... and bill to end destructive swordfish drift gillnet fishing off California}

California state has passed Senate Bill 1017 which will phase out the use of large-scale driftnet fishing for swordfish over a 4-year period, establish a buyout programme and incentivize the use of fishing gear that reduces the incidental catch of marine wildlife. Long, nearly invisible mesh nets are still allowed to drift overnight in waters off California to capture swordfish. They often also entangle, injure and kill more than 70 different species of ocean wildlife, including marine mammals such as whales, dolphins and sea lions, and threatened sea turtles, sharks and other important fish species. According to federal onboard observers, on average more than half of bycatch is tossed overboard already dead or dying. Drift gillnet fishermen will now be compensated for the value of their drift gillnet permit and must surrender their nets.

Source: Oceana (2018) usa.oceana.org/pressreleases/governor-brown-signs-bill-enddestructive-swordfish-drift-gillnet-fishingcalifornia

\section{Diverse family of algae could help corals survive warming seas}

Scientists have found that some corals have a chance of surviving the current rise in global sea temperatures thanks to the diversity of their algal counterparts. Research has indicated that the alliance with algae that allows corals to form reefs is much older than previously thought (c. 160 million years) and that the algal species that corals associate with could determine their chances of recovery from stress. The team sequenced the DNA and compared the genomes of dinoflagellate algae inside corals and examined the morphological differences between members of the algal family Symbiodiniaceae using a combination of high-powered microscopes and computer modeling. Findings suggest that algal diversity, combined with the family's age, probably helped corals to begin constructing reefs on a grand scale and could boost corals' resistance to higher ocean temperatures. Scientists are now proposing a new naming scheme for Symbiodiniaceae algae, which will facilitate future research.

Sources: Current Biology (2018) doi.org/10. 1016/j.cub.2018.07.008, \& Mongabay (2018) news.mongabay.com/2018/o9/diverse-familyof-algae-could-help-corals-survive-climatechange/

\section{France becomes first country in Europe to ban all five pesticides killing bees}

France will take a radical step towards protecting its dwindling bee population by becoming the first European country to ban all five pesticides researchers believe are killing off the insects, known as neonicotinoids. Introduced in the mid 1990s, synthetic neonicotinoids share the chemical structure of nicotine and attack the central nervous system of insects. The ban has been welcomed by beekeepers and environmentalists, but cereal and sugar beet farmers warn it could leave them defenceless in protecting valuable crops against other harmful insects. By enforcing the blanket ban, France is going further than the European Union, which voted to outlaw the use of three neonicotinoids-clothianidin, imidacloprid and thiamethoxam-in crop fields. France has also banned thiacloprid and acetamiprid. A report by France's ANSES public health agency said there were sufficiently effective and operational alternatives to the majority of neonicotinoids used in France.
Source: The Telegraph (2018) telegraph.co. uk/news/2018/o8/31/france-first-ban-fivepesticides-killing-bees/

\section{Evidence of sturgeon breeding in Georgia}

Once widespread throughout Europe's major rivers, sturgeon have been fished to near extinction for their meat and caviar. With only three breeding populations in the entire continent, action is urgently needed to reverse their decline. In 2018 Fauna \& Flora International conducted the first baseline studies for sturgeons in the Rioni river in Georgia and started to address poaching and illegal trade. Georgian students have undergone training on the Danube and are now gathering scientific data on the remaining sturgeon in the Rioni. They have been able to capture, and release, a baby sturgeon, $<10 \mathrm{~cm}$ long and covered in sharp, bony scutes that protect it from predators, which was identified as a Critically Endangered stellate sturgeon Acipenser stellatus. There had been uncertainty about whether these fish were still reproducing in the Rioni, so this important find gives hope for their future.

Source: Fauna \& Flora International (2018) fauna-flora.org/news/little-fish-big-dealbaby-sturgeon-offers-hope-future

\section{Couple purchase 10,000 ha for conservation}

Jack and Laura Dangermond, owners of technology company ESRI, have paid USD 225 million to save a part of California's coastline from development, in the biggest ever donation to The Nature Conservancy. The previous ranch, covering 10,00o ha of pristine coast, forests, hills, canyons and grasslands, is particularly rich in biodiversity as a result of the cold and warm water currents that meet beyond its shores. It also includes hundreds of sites of historic significance. Called Point Conception by Spanish explorers, for the Native American Chumash it was a place for the end of life, its waters representing the portal to the next world. The Dangermonds bought the land when it was threatened by housing development and decided to protect it in perpetuity. Their environmental passion is founded on the data that drives the digital mapping that they pioneered.

Source: $A B C$ News (2018) abc.net.au/news/ 2018-09-11/esri-founders-spend-225-millionon-california-nature-preserve/10221170 


\section{Building conservation optimism through the study of bright spots}

To be effective, scientific knowledge must be translated into policy and practice, but achieving demonstrable impacts of scientific evidence on decision-making remains difficult. Efforts to examine this phenomenon have often focused on situations where science has failed to inform policy or practice, leading to the widespread use of pessimistic terms such as 'science-policy gap' and a perception of disconnect between academic research and measurable impacts. A shift in the academic study of science-policy-practice interfaces is therefore needed towards the study of bright spots-situations in which environmental science has successfully influenced policy and/or practice. Systematic documentation of success can lead to a new mantra of optimism, which in turn can mobilize people for action and encourage knowledge sharing and cooperation. Studies of bright spots also help to identify the key principles underpinning success, supporting the development of effective strategies for successful conservation.

Source: Nature (2018) nature.com/articles/ s41467-018-05977-w

Kedah protects forests from logging. . . The government of Kedah in northern Malaysia has revoked logging permits and suspended the issuance of new ones in Ulu Muda Forest Reserve, sacrificing its revenue from forest premiums for the sake of water security and environmental conservation. Fiscal reforms are now needed to ensure the state is compensated appropriately for the ecosystem services the forest complex provides beyond Kedah's boundaries. The Ulu Muda catchment area provides water for drinking and agricultural use in the three states of Perlis, Kedah and Penang, fuelling the nation's biggest granary area, the region's economy, and its people's livelihoods and well-being. The forest complex is also a biodiversity hotspot with at least 112 mammal species, including Asian elephants, tapirs, sun bears, sambar deer and clouded leopards. The Reserve is one of the two known places in Peninsular Malaysia where spotted leopards occur, and its population of the rare plainpouched hornbill attracts local birdwatchers and international tourists alike.

Sources: The Star (2018) thestar.com.my/ news/nation/2018/09/05/no-more-loggingin-ulu-muda-kedah-revokes-and-halts-issu ing-new-permits-for-felling-trees/, \& WWF (2018) wwf.org.my/?26025/Time-forBeneficiaries-to-assist-Kedah-in-conservingUlu-Muda

\section{... and 200 plants two millionth tree in Madagascar}

Omaha's Henry Doorly Zoo and Aquarium, together with Madagascar Biodiversity Partnership (MBP), planted its two millionth tree in Madagascar in August 2018. Since 2012 the organizations' reforestation efforts have focused on providing habitat for lemurs, the most threatened group of mammals, by working with the communities who depend on the same resources. Nearly all species of lemurs, which are endemic to Madagascar, are threatened as their habitat is lost to deforestation. Commercial trees, such as bamboo, banana and cinnamon, are a vital part of the reforestation programme as they provide community members with additional income. Each tree grown for the project begins as a seedling and is nurtured to maturity within a nursery by Zoo staff, MBP and the local community. The Zoo and MBP reached their 5-year goal to plant one million trees in 2017. Fueled by the support of the Arbor Day Foundation, they were able to plant an additional one million trees in less than 2 years.

Source: Omaha Zoo (2018) omahazoo.com/ inthenews/posts/zoo-plants-two-millionthtree-in-madagascar

\section{As Colombia battles deforestation, other post-conflict regions show there's hope for conservation...}

Since the end of prolonged armed conflicts in 2016, nearly 400,000 ha of forest have been lost in Colombia's previously inaccessible areas that are now open to exploitation. However, as conflict ends, there are also opportunities for balancing socioeconomic development and environmental conservation to bring sustainability and stability to affected people and areas. Examples of such efforts include Myanmar, where the end of conflicts in 2015 has enabled the establishment of rubber plantations on previously degraded land, and Lao, where, since the Viet Nam war ended, rattan is being grown as a sustainable cash crop. These countries faced the same challenges as Colombia-land rights, ethnic and social disruption and finding suitable crops to grow. Colombians hope that an approach including restoration of productivity in the country's northern savannah, the use of sophisticated vegetation monitoring systems, and establishment of grassroots community projects can help prevent large-scale deforestation.

Source: NBC News (2018) nbcnews.com/news/ latin-america/colombia-battles-deforestati on-other-post-conflict-regions-show-theres-n9o7811
... and women are healing the scars of
war in Mozambique wildlife park The 4,000 km² Gorongosa National Park in Mozambique has been severely affected by years of civil war following the country's declaration of independence from Portugal in 1975. Rebels based around Mount Gorongosa killed c. $90 \%$ of the park's larger animals for meat or to trade their ivory for weapons. Recovery began in 2008, when a non-profit foundation signed a 2o-year contract with the government to manage and rebuild the Park. In 2017 an education programme was set up for girls from the Park's buffer zone, who are affected by poverty and often married as teenagers. Now 2,00o girls attend educational clubs across 50 schools, visiting the Park and experiencing its rebounding wildlife first-hand. Meetings also cover literacy and opportunities to discuss the disadvantages of becoming a child bride. The Park's science department, which is led by female researchers and aims to inform ongoing restoration efforts, also offers internships for girls, to support their education and development.

Source: The Guardian (2018) theguardian. com/global-development/ng-interactive/2018/ sep/o7/women-gorongosa-national-park-heal ing-scars-of-war-mozambique

\section{Triumph for tigers: numbers on the rise in Nepal}

Tiger numbers are on the rise in Nepal. Data from camera-trap surveys conducted across most of the nation's tiger habitats in 2017-2018 have shown that the country is now home to c. 235 individuals. This marks a $19 \%$ increase in estimated tiger numbers compared to a 2013-2014 nationwide felid survey, most notably in Parsa and Banke National Parks. Although it was declared a wildlife reserve in 1984, villagers from inside Parsa only agreed to resettle outside the park in 20092010. In Banke, which was declared a national park in 2010 and is Nepal's newest protected area, villagers relocated from the park's core to create disturbancefree habitats, thus decreasing poaching opportunities through reduced access to the heart of the reserve. Resettlement was voluntary in all cases, with added governmental benefits. Heightened army patrol presence, together with efforts to increase the prey base in the parks through grassland and wetland restoration, have also helped tigers recover.

Source: Panthera (2018) panthera.org/blog/ 2018/og/24/triumph-tigers 


\section{INTERNATIONAL}

\section{Long-banned toxin may wipe out many} killer whales

A 2018 study suggests that more than half the world's killer whale populations face collapse within 30-50 years as a result of exposure to toxic chemicals, despite their manufacture being outlawed since the 1970s. Polychlorinated biphenyls (PCBs) are organic compounds with a range of industrial applications, but their extreme toxicity led to widespread restrictions on their use since 1974, culminating in a worldwide ban in 2004. However, PCBs persist in the marine environment, working their way up the food chain and accumulating in apex predators in concentrations that pose significant risks to seals, sharks, and particularly killer whales, whose immune systems and reproductive health are seriously compromised. An international team of ecotoxicologists, veterinary pathologists and marine biologists used data on $\mathrm{PCB}$ concentrations in orca tissues to model the impact on their long-term viability, predicting dramatic declines as a consequence of reproductive failure in populations with increased chemical exposure.

Source: National Geographic (2018) national geographic.com/environment/2018/o9/orc as-killer-whales-poisoned-pcbs-pollution

\section{Reducing demand for illegal wildlife products: strategies to change consumer behaviour}

A new study investigating effective approaches for changing the behaviour of consumers of illegal wildlife products was launched in September 2018, to support efforts to suppress the demand that fuels wildlife crime. The report maps a wide range of demand reduction initiatives, contains primary research to test innovative methods to understand demand and motivators for the consumption of elephant and rhino products, and features a review of Chinese and Vietnamese language literature on approaches to influencing consumer choice and behaviour. Based on their findings, the authors make recommendations for future behaviour change interventions. Behavioural science should be the foundation of such initiatives, efforts to share findings amongst organizations must be increased, and multiple ways of reaching the target audience to reinforce the message over time need to be adopted for such campaigns to be effective.

Source: TRAFFIC (2018) traffic.org/publica tions/reports/reducing-demand-for-illegalwildlife-products/

\section{New global study reveals staggering loss of forests caused by industrial agriculture}

A new analysis of global forest loss reveals that industrial agriculture is contributing to the loss of c. 5 million ha per year. Despite companies pledging to help reduce deforestation, the amount of forest cleared to plant oil palm and other crops remained steady between 2001 and 2015. These findings suggest that corporate commitments alone will not adequately protect forests from expanding agriculture. Researchers already had a detailed global picture of forest loss and regrowth. Recognition of five causes of forest loss in satellite images (wildfire, logging of tree plantations, large- and small-scale agriculture, and urbanization) showed that c. $27 \%$ of the total loss between 2001 and 2015 was a result of large-scale farming and ranching. Such farming includes industrial plantations for palm oil, a valuable biofuel and a major ingredient in food, cosmetics and other products.

Sources: Science (2018) doi.org/10.1126/science.aau 3445 , \& sciencemag.org/news/2018/ og/scientists-reveal-how-much-world-s-forests-being-destroyed-industrial-agriculture

\section{How DNA testing could bring down ivory trade's biggest criminals}

Up to 40,000 African elephants are lost to poaching each year. Genetic testing has implicated three of the largest export cartels trafficking tusks out of Africa during the peak of ivory trade during 2011-2014. Ivory is almost always shipped out of a country other than that in which it is poached, and traceability becomes harder once it leaves Africa, burdening law enforcement agencies. The team focused on linking individual shipments back to the export cartels consolidating tusks, hoping to map the network of illegal trade within African borders before ivory is lost to global dispersal. By analysing DNA from 38 samples of large ivory seizures made during 2006-2015 they determined that 26 samples from separate seizures matched tusks from another shipment. DNA testing may help law enforcement teams tackle trafficking at ports and further up the chain.

Sources: Science Advances (2018) doi.org/10. 1126/sciadv.aato625, \& Smithsonian Magazine (2018) smithsonianmag.com/smartnews/how-dna-testing-could-bring-downivory-trades-biggest-criminals-180970332/

\section{Indigenous lands crucial for conservation}

Spatial information on Indigenous lands has been aggregated for the first time on a global scale, revealing that Indigenous Peoples manage, or have tenure rights to, over a quarter of the world's land surface. Analysis of publicly available geospatial resources has revealed that Indigenous Peoples manage or own at least 38 million $\mathrm{km}^{2}$ across 87 countries or politically distinct areas. The areas occur in all inhabited continents and intersect with c. $40 \%$ of all terrestrial protected areas and ecologically intact landscapes. The spatial overview reveals the scale of Indigenous Peoples' influence and emphasizes the need to recognize their rights to land, benefit sharing and institutions to meet local and global conservation goals. The findings will contribute to global understandings of the conservation value of Indigenous Peoples' lands and it is hoped that this will catalyse collaborative partnerships between Indigenous Peoples, conservation practitioners and governments. Sources: UNEP-WCMC (2018) unep-wcmc. org/news/indigenous-lands-are-globallyimportant-for-conservation--new-studyfinds, \& Nature Sustainability (2018) nature. com/articles/s41893-018-010o-6

\section{Only $13 \%$ of the world's oceans are still untouched wilderness}

The first comprehensive analysis of marine wilderness has found that only $13.2 \%$ of the oceans are undamaged by humans. Global shipping, fishing operations and pollution have all significantly affected the seas. Areas of true wilderness, mostly found in the polar regions and around remote Pacific Island nations, are vital as they represent some of the most diverse parts of the ocean and the last places still inhabited by high numbers of large predators such as sharks. The few fragments left are increasingly threatened as advanced fishing technologies and melting sea ice expose them to human activity. The researchers have urged for international agreements to recognize the value of these areas, as currently $<5 \%$ of them are protected. Efforts are being made to protect some of the remaining wilderness regions, such as pushing for the creation of the world's largest marine sanctuary in Antarctica.

Sources: Current Biology (2018) doi.org/10. 1016/j.cub.2018.06.010, \& The Independent (2018) independent.co.uk/environment/ oceans-conservation-arctic-pacific-islandsmarine-fishing-climate-change-a8465401. html

\section{Endangered eel larvae make a tasty treat for fish in an ocean desert}

Numbers of the once common European eel Anguilla anguilla have declined precipitously in the past 45 years. This species spends its adult life in estuaries and rivers, 
heading to the Sargasso Sea to reproduce, but the number of larvae that make their way back to Europe via the Gulf Stream has dropped by $90 \%$. These larvae were once considered too difficult for most predators to spot and catch. However, a new study looking at traces of eel DNA in the guts of fish near eel breeding waters identified at least six different predator species. This discovery could help reveal the true diets of these predatory fish, and their role within the oceanic food web.

Sources: Marine Biology (2018) doi.org/10. 1007/soo227-018-3390-3, \& Science (2018) sciencemag.org/news/2018/o8/endangeredeel-larvae-make-tasty-treat-fish-ocean-desert

\section{An international plan to save the helmeted hornbill}

Conservation organizations from across the world have developed an ambitious 10-year, range-wide conservation strategy plan to end the illegal hunting currently threatening the Critically Endangered helmeted hornbill Rhinoplax vigil. This bird, found in the forests of South-east Asia, has been driven to the brink of extinction by poaching following rising demand for its striking red casque, which can be carved into decorative artifacts. Over 2,500 illegally traded casques have been seized in the last 8 years, but stopping the illegal trade has proved difficult. Despite being protected under CITES since 1975, weak implementation and enforcement have led to growing illegal trade. The plan outlines actions to be taken over the next decade, including mapping potential trade routes and hubs of hornbill casque carving, identifying priority areas for protection and enforcement, and community engagement efforts. Source: BirdLife (2018) birdlife.org/worldwide/news/international-plan-savehelmeted-hornbill

\section{Pro-whaling nations block South Atlantic whale sanctuary}

A proposal to create a whale sanctuary in the South Atlantic was defeated at a meeting of the International Whaling Commission in Brazil, amid a clash between countries that think whales can be hunted sustainably and others that want more conservation measures. Pro-whaling nations, including Japan, Korea, Norway and Russia, argued the science did not support the case for a sanctuary and said it was not necessary because there isn't any commercial whaling occurring in the South Atlantic. The measure received support from 39 countries at the meeting in Florianopolis, with 25 opposed, falling short of the three-quarters majority to pass. Countries such as Brazil, which proposed the measure, said it would have addressed threats to marine mammals beyond whaling. Humane Society International called the defeat a bitter disappointment and said it would have helped protect whales from entanglement in fishing gear and ship strikes.

Source: The Guardian (2018) theguardian. com/environment/2018/sep/12/pro-whalingnations-block-south-atlantic-whale-sanctuary

\section{Global warming pushing alpine species higher}

Researchers from the University of British Columbia have carried out the first broad review of shifts in the elevation range of 975 populations of plants, insects and animals from 23 previous surveys and studies, largely conducted over the past 50 years. They found that for every $1^{\circ} \mathrm{C}$ increase in temperature, mountaintop species move $100 \mathrm{~m}$ upwards, shrinking the area available to them and resulting in dramatic population declines. Results also showed that a few species, such as the whitecrowned sparrow in the southern Sierra Nevada mountains in California, moved their entire range down mountains, highlighting how complicated responses to climate change are likely to be. Although we may be able to predict what happens on average, predicting how any particular species will respond remains a considerable challenge.

Sources: Global Ecology \& Biogeography (2018) doi.org/10.1111/geb.12774, \& Phys.org (2018) phys.org/news/2018-o9-global-alpinespecies-higher.html

\section{Ambitious ocean plastic clean-up system deployed for testing in the Pacific}

A high-profile and controversial effort to collect and haul away plastic pollution in the Pacific ocean was launched from San Francisco Bay in September 2018. The Ocean Cleanup, a non-profit organization based in Rotterdam, built the device with the aim of retrieving plastic debris from the Great Pacific Garbage Patch. The system is designed to receive floating plastic propelled by ocean currents into curved floating booms, which funnel the debris toward a central tank to be collected monthly by ships. Sceptics suggest that addressing the more challenging issue of preventing plastic from entering the marine environment at source would be a more effective use of resources. The Ocean Cleanup maintains that action must be taken at both ends of the plastic pollution chain, claiming its operation to remove litter already found in the marine environment will play a supporting role alongside efforts to intercept it before it gets there.
Source: Science (2018) sciencemag.org/news/ 2018/og/still-controversial-plastic-trash-coll ector-ocean-begins-maiden-voyage

\section{Commonwealth countries unite to tackle ocean plastic pollution}

Australia, Fiji, Kenya and St Lucia have officially joined the Commonwealth Clean Oceans Alliance, which aims to unite countries around the Commonwealth in reducing the amount plastic pollution entering the marine environment. Each member has pledged to take action to eliminate avoidable plastic waste, such as the banning of microbeads or reduction in the use of disposable plastic bags. The Alliance's latest partners will work with existing members New Zealand, Sri Lanka and Ghana, as well as initiative leaders Vanatu and the UK, to create a nine-strong coalition in the fight plastic pollution. The UK environment minister described marine plastics as one of the greatest environmental challenges globally, announcing support for Commonwealth countries in the form of the GBP 61.4 million Commonwealth Oceans Plastic Package, in addition to the broader Global Plastics Action Partnership, a GBP 2.4 million project to tackle global plastic pollution in rivers, deltas and oceans.

Source: UK Government (2018) gov.uk/gov ernment/news/commonwealth-countriesunite-to-tackle-ocean-plastic-pollution

\section{EUROPE}

\section{Sweden's reindeer facing starvation...}

Following recent droughts, Swedish reindeer herders warn that without imminent government action, their reindeer could starve. An $80-100 \%$ reduction in rainfall last summer dramatically affected farming and wildlife conservation. Although the government has concrete plans for dealing with future heat waves, Sweden's 4,600 Sami reindeer owners claim they are not getting the help they need to keep their animals alive. The semi-nomadic Sami people span Norway, Sweden, Finland and Russia, but they do not own, and therefore cannot alter, the land on which their reindeer graze. Given their recognized status as an Indigenous People, international law must protect their way of life, and the Sami say they need laws that allow them to cultivate the land to support the reindeer. The Swedish Government has indicated it is keen to provide assistance, such as supplying feed and reducing feed costs, but is waiting for a full report from Sami representatives. 
Source: Care2 (2018) care2.com/causes/ swedens-reindeer-are-facing-starvation.html

\section{... and UK heatwave takes its toll on wildlife}

A prolonged period of unusually high temperatures and associated drought in the summer of 2018 has left many species of British wildlife struggling to survive. Hedgehogs, moles and badgers, for example, did not find enough food because worms, slugs and beetles retreated deep underground to avoid the extreme conditions at the surface. Birds and amphibians have suffered, too, as their water sources dried up. Citizens have been encouraged to take action to help wildlife, such as leaving out bowls of water and food for hedgehogs, and constructing pools of water in their gardens to sustain amphibians. Scientists have warned that heatwaves are likely to be become more frequent and more severe as a result of climate change. However, a warmer, drier future could be beneficial for some animals, with reptiles such as common lizards and grass snakes expected to increase their range northwards.

Source: The Independent (2018) independent. co.uk/news/uk/home-news/uk-heatwavewildlife-hedgehogs-frogs-birds-sun-hottemperature-climate-change-a8466891.html

\section{Common cranes recolonize England after 400-year absence. .}

The common crane Grus grus probably became extinct in the UK as a breeding species during the 16th century, having previously featured regularly on the menus of medieval feasts. Since the late 1970s, however, the birds have started to recolonize the country. There were only five pairs in 2000 , and until 2010 much of the initially slow population growth was a result of new arrivals from continental Europe. Then conservationists released fledgling cranes as part of the Great Crane Project, which by 2014 had boosted the population with 90 new birds. A new population model now predicts a $50 \%$ increase in the number of breeding cranes, from 178 now to 275 pairs in the UK in 50 years' time. The availability of large protected wetlands has been vital for the species' recovery: over $80 \%$ of the breeding population is currently found on protected sites.

Sources: The Guardian (2018) theguardian. com/environment/2018/jul/17/common-

cranes-here-to-stay-after-recolonising-east ern-england, \& RSPB (2018) rspb.org.uk/ community/ourwork/b/biodiversity/archive/ 2018/07/17/it-39-s-not-all-doom-and-gloomthe-recovery-of-the-uk-crane-population. aspx

\section{.. pine marten spotted in Kielder forest for first time in $\mathbf{9 0}$ years. .}

The pine marten Martes martes, previously driven to extinction in England, has returned to Northumberland for the first time since 1926. Stills and video from a volunteer's camera trap recorded a mature pine marten eating peanut butter put out for red squirrels in Kielder forest. It is the most conclusive evidence of a resident pine marten population in Northumberland and confirms the resurgence of a once-persecuted and still extremely rare mammal. In the last 3 years pine martens have been spotted in Shropshire and the New Forest. Their numbers in Wales are increasing and there are plans to reintroduce them into the Forest of Dean in 2019. For decades, the pine marten was killed by gamekeepers protecting their game birds but conservationists seeking to save the native red squirrel are particularly keen for the pine marten's return because it predates on invasive grey squirrels.

Source: The Guardian (2018) theguardian. com/environment/2018/aug/15/pine-martenspotted-in-northumberland-for-first-time-in90-years

\section{... after $\mathbf{3 0}$ years water voles return to national park in west country...}

Once regularly spotted on Britain's riverbanks, water voles are now the nation's fastest declining land mammal, disappearing from $94 \%$ of their former sites as a result of increased urbanization, predators and a decline in natural habitat. Locally extinct for $>3$ decades, 150 water voles have been released at six locations in the Aller river on the Holnicote Estate on Exmoor in Somerset. Rangers, volunteers, students and members of the public will be closely monitoring the new arrivals, using simple field signs to record their presence and behaviour. The streams and banks can be easily seen from many of the footpaths on the estate, and because the species is diurnal it should once again become a regular sight in the area. The water voles will be released in sibling groups and breeding pairs. A further 150 will be released in the spring.

Source: The Guardian (2018) theguardian. com/environment/2018/sep/11/water-volesreturning-to-national-park-in-west-countryafter-30-years

\section{... and northern bald ibis once again takes to European skies}

The Critically Endangered northern bald ibis Geronticus eremita historically occurred widely in northern and eastern Africa, Anatolia, Arabia and parts of Europe. Today, the species is close to extinction in the wild, with 600 wild birds in Morocco, a semi-wild population of 200 individuals in southern Turkey, and possibly a few individuals in East Africa. Now, however, efforts are underway to reintroduce the birds to the northern fringe of the Alps, where they disappeared nearly 400 years ago. As part of this ambitious and controversial project, conservationists are teaching captive-bred birds to migrate south by leading them in ultralight aircraft towards the Mediterranean. The project has been criticized for using birds that have lived in captivity for a long time and for relying heavily on technology, with some arguing it would be better to focus resources on the increasing Morocco population and on rewilding efforts in Turkey.

Source: Yale School of Forestry \&

Environmental Studies (2018) e360.yale. edu/features/after-a-40o-year-absence-wald rapp-rare-ibis-returns-to-european-skies

\section{NORTH EURASIA}

\section{New road threatens the giant noctule, Europe's biggest bat}

After its first recorded sighting in Belarus in 1930, the elusive giant noctule Nyctalus lasiopterus was never seen in the country again throughout the rest of the 2oth century. In 2015, however, scientists rediscovered it in Stary Žadzien, a remote forest and wetland area in south Belarus. With a weight of $80 \mathrm{~g}$ and a wingspan of up to $46 \mathrm{~cm}$, this is Europe's largest bat. Categorized as Vulnerable by the IUCN, it is also one of Europe's least studied species. For the last 4 years, APB-BirdLife Belarus has been conducting scientific expeditions to study the bats, which rely on undisturbed natural habitats. A new road is currently being built through Almany Mires, only $20 \mathrm{~km}$ away, devastating one of Europe's most ancient and important bogs. Conservationists hope that the giant noctule's return to Belarus reinforces the importance of protecting such rare habitats from human destruction.

Source: BirdLife International (2018) birdlife. org/europe-and-central-asia/news/searchgiant-noctule- $\% \mathrm{E}_{2} \% 80 \% 93$-europe $\% \mathrm{E}_{2} \%$ 80\%99s-biggest-bat

\section{Rare birds of prey take flight in Kazakhstan}

Birds of prey in Kazakhstan are threatened by poaching, the illegal capture of nestlings for use as hunting birds, electrical power lines, traps and poison baits. In the autumn of 2018, four golden eagles were released into 
the wild as part of a conservation programme. The chicks were born at the privately owned Sunkar sanctuary in Almarasan near Almaty. Sunkar breeds birds of prey both for legal sale and for release into the wild, and 25 golden eagles have been released since 2013. The centre also breeds and releases saker falcons, which are categorized as Endangered on the IUCN Red List. From birth, the birds that will be returned to the wild are raised differently from those bred for commercial purposes, isolated from humans in an aviary from which they can see only the sky and the surrounding slopes of the Ile Alatau mountains.

Source: Eurasianet (2018) eurasianet.org/ kazakhstan-rare-birds-of-prey-take-flight

\section{Recovering saiga face a double threat} Despite signs of a gradual recovery from the devastating mass die off suffered by Saiga tartarica at the hands of bacterial infection in 2015 , the antelope also faces continued threat from poachers seeking to traffic their horns. Monitoring and protection measures to ensure the health of saiga populations are confronted with increasing interference from poachers. Studies have revealed high demand for saiga horn products in Asian countries, where the continued legal sale of products from reserves dating back to the 1990 os makes it easy for traffickers to launder newly poached, illegal horn with limited risk of detection. Poachers are better paid and better equipped than rangers, and because corruption hinders enforcement efforts and curbing demand for saiga horn among consumers is so difficult, conservationists and government officials aim to focus on improving the livelihoods of illegal hunters and rangers, to incentivize the protection of saiga and discourage poaching.

Source: National Geographic (2018) nationalgeographic.com/animals/2018/ o8/saiga-antelope-poaching-disease/

\section{NORTH AFRICA AND} MIDDLE EAST

\section{Seven Mediterranean countries launch project to protect wetlands}

Wetlands in North Africa, including oases, freshwater marshes, coastal lagoons and salt marshes, are threatened by intensification of agriculture, urban development, infrastructure projects, and mineral extraction. Together, these factors contribute to the decline of many fish species, disrupting the movement of migratory waterbirds such as ducks, geese, and terns. Representatives from seven countries in the Mediterranean -Morocco, Algeria, Tunisia, Libya, Turkey, Lebanon and Jordan-have launched a wetland conservation project in Tunis in October 2018, with support from several NGOs and development agencies. Building capacity is the main objective, so that organizations working to protect wetlands are better equipped for their mission. The project also involves setting up a waterbird counting network to measure the ecological status of wetlands. Another focus is on partnership with civil society to develop and implement six micro projects in wetlands with high biodiversity and cultural heritage value.

Source: Afrik21 (2018) afrik21.africa/en/5517-2/

\section{Public encouraged to download eTurtle app in Cyprus}

The Oceanographic Centre at the University of Cyprus is encouraging the public in Cyprus to download a smartphone app for collecting information on observations of sea turtles in the wild. The eTurtle app is available in English, Italian, Greek, Croatian, Slovenian and Maltese. It was developed by the Croatian Natural History Museum and its partners in the LIFE Euroturtles project, co-funded by the EU. The project involves nine organizations from six Mediterranean countries. Citizens and fishers can upload turtle observations via the app, to improve the conservation status of loggerhead and green turtles. A greater quantity and quality of data on turtles will help improve the management and protection measures for these animals, which are threatened by fishing gear, light and noise pollution on the nesting beaches, nest predation by foxes, and increased boat traffic during the tourist season.

Source: Cyprus Mail (2018) cyprus-mail.com/ 2018/og/24/public-encouraged-to-downloadeturtle-app/

\section{Kurdish conservationists working for Persian leopards in Iraq}

The Persian leopard Panthera pardus saxicolor is the largest of nine leopard subspecies. It is categorized as Endangered on the IUCN Red List, with estimates suggesting that fewer than 1,290 adults remain. In an area where human conflict leaves little room for environmental concerns, and despite the leopards' elusive nature, Kurdish conservationists have demonstrated their presence in the Zagros Mountains in Iraq. A first camera-trap image was obtained in 2011, and two more in the following 4 years. The team have since documented the predator's habitat and are advocating the designation and management of reserves, arguing that protecting the leopard's habitat will help other threatened species such as the spur-thighed tortoise, Azerbaijan and Kurdistan mountain newts and spotted belly salamander. They hope that their efforts to protect leopards will help change priorities in the country and shift direction towards nature and conservation.

Source: Discover Magazine (2018) blogs. discovermagazine.com/crux/2018/o9/21/ iran-golestan-persian-leopards/

\section{SUB-SAHARAN AFRICA}

\section{WWF Restoring the collapsing Semuliki river bank in Uganda}

River Semuliki, which marks the natural boundary between Uganda and the Democratic Republic of Congo, is a major livelihood source for neighbouring farming communities, providing water for livestock and crops. However, rising water, poor farming methods upstream, overgrazing and population pressure have contributed to the weakening of the river banks, which eventually burst, causing the river to widen on either side and leading to land loss in both countries. WWF Uganda Country Office is working with local collaborators and communities to pilot a river bank restoration scheme to mitigate further damage. So far, they have restored $5.2 \mathrm{~km}$ of river bank through buffer zone establishment and bank stabilization with local materials such as bamboo and water reeds. The buffer zone, in agreement with the landowners, has been cordoned off to limit cattle grazing and other forms of land use that weaken the banks.

Source: WWF (2018) wwf.panda.org/wwf_ offices/uganda/news2222/?335142\%2FWWFRestoring-the-Collapsing-Semuliki-RiverBank-in-Uganda

\section{Participatory approach key to forest management in the DRC}

Central Africa is home to the second largest expanse of tropical forest in the world, the greatest part of which covers 160 million ha in the Democratic Republic of Congo (DRC) and provides the primary source of food, shelter and income for c. 40 million people. Eighty per cent of the DRC's intact forests are found outside protected areas, and failure to recognize Indigenous rights has undermined forest management. The Batwa, Indigenous hunter-gatherers, account for $20 \%$ of the population of the Kabobo Massif in eastern DRC but illegal 
taking of their land and continued armed conflict has prevented the Batwa from effectively conserving these varied forests. Following a 10-year process supported by the Wildlife Conservation Society and the provincial government, the Batwa are now equal partners in the newly established 150,000 ha Kabobo Wildlife Reserve and play a key role in defining reserve boundaries and managing resource use.

Source: National Geographic (2018) blog. nationalgeographic.org/2018/o9/10/securingintact-forests-and-indigenous-livelihoods-indr-congo/

\section{Elephant poaching on the rise in Botswana}

The NGO Elephants Without Borders (EWB) reported that during aerial surveys carried out around the Okavango Delta in Botswana in July-August 2018 they counted at least 87 elephants killed by poachers. These surveys are conducted jointly between EWB and the government every 4 years. At the point of reporting, the 2018 survey was only halfway through, and conservationists worried the final number of poached elephants would continue to rise. The government of Botswana, however, has refuted the NGO's claims and called the figures unsubstantiated in a statement published on Twitter. Botswana is estimated to have c. 130,0oo elephants, and is considered the last safe haven for the species. The Director of EWB believes that the recent decision by Botswana's new president to disarm the country's antipoaching unit is partly to blame for the spike in elephant poaching in the country. Source: Mongabay (2018) news.mongabay. com/2018/og/87-elephants-found-dead-inbotswana-one-of-last-safe-havens-for-thespecies/

\section{Last South African coelacanths threatened by oil exploration}

Bright blue and older than dinosaurs, coelacanths are the most threatened fish in South Africa and among the rarest in the world. Only c. 30 of these Critically Endangered fish are known to exist off the east coast of South Africa, raising concern that a new oil exploration venture in the area could jeopardize their future. Coelacanths, whose shape has remained almost unchanged for 420 million years, were once feared extinct, but have since been found in small populations, including the recent discovery of a colony in South Africa's Sodwana Bay. However, the Rome-based energy group Eni now plans to drill several deep-water oil wells in a $400 \mathrm{~km}$ long exploration block. There was little mention of the potential threat to the Sodwana coelacanths in Eni's environmental impact assessment report, and conservationists are concerned that any oil spills or blowouts during exploration could seriously threaten this fish, which is sensitive to environmental disturbance.

Source: The Guardian (2018) theguardian. com/environment/2018/aug/17/older-thandinosaurs-last-south-african-coelacanthsthreatened-by-oil-exploration

\section{Record-breaking number of whales sighted in South African hotspot}

A 7-hour flight over the coast to the east of Cape Town in South Africa has identified a record of 1,347 southern right whales in the area in August 2018. Numbers are thought to be almost triple those observed a year ago and emphasize the importance of the region as a breeding ground for the species. Marine conservation photographers and scientists recorded 661 mother-and-calf pairs during the flight over the shoreline and 558 of these pairs were found in the De Hoop Nature Reserve, an area renowned for its whale sightings. The aerial survey in August 2018 was co-funded by CapeNature, the organization responsible for managing De Hoop Nature Reserve, in an effort to understand the demographics of the southern right whale population and safeguard the long-term health of the species.

Source: Lonely Planet (2018) lonelyplanet. com/news/2018/o8/29/de-hoop-naturereserve-whales/

\section{SOUTH AND SOUTH-EAST ASIA}

\section{Deforestation and hunting driving bird extinction}

Scientists have warned that the combined impact of deforestation and wildlife exploitation on bird numbers is severely underestimated and could lead to some species becoming extinct. Symes et al. (2018) focused on Sundaland, a hotspot of biodiversity spanning Borneo, Sumatra, Java and Peninsular Malaysia, which experiences intense habitat loss, hunting and wildlife trade. Looking at 308 forest-dependent bird species, they found that $89 \%$ had experienced a mean habitat loss of $16 \%$ because of deforestation, and that wildlife exploitation had led to a mean population decline of $37 \%$. They also identified 77 commercially traded bird species that are more commonly exploited. The estimated mean decline for these exploited species was $15.3 \%$ from deforestation alone, but when combined with the effects of exploitation, it increased to $51.9 \%$. The researchers caution that 50-90 of forest-dependent bird species in the region will be extinct by 2100 . Sources: Nature Communications (2018) doi.org/10.1038/s41467-018-06579-2, \& Asian Scientist (2018) asianscientist.com/ 2018/10/in-the-lab/southeast-asia-birdextinction

\section{Indonesian government puts off Sumatran rhino IVF programme}

Hopes for a long-awaited collaboration between Indonesia and Malaysia to breed the near-extinct Sumatran rhino Dicerorhinus sumatrensis are fading fast, as the last of the species weaken amid government inaction. Conservationists in both countries have long pushed for in vitro fertilization (IVF) of this Critically Endangered species. Indonesia has c. 100 individuals, and Malaysia has just two. Researchers hope to use sperm from one of Indonesia's captive male rhinos to fertilize eggs from the lone remaining female of the species in Malaysia. However, the Indonesian government's hesitance in making the sperm available or applying for a permit that would allow Malaysia to send over the eggs is hindering efforts. Meanwhile, Indonesian officials blame the lack of progress on the Malaysian rhino's fertility problems. A successful attempt at producing a viable Sumatran rhino embryo through IVF would add much-needed diversity to the captive population.

Source: Mongabay (2018) news.mongabay. com/2018/10/indonesian-government-putsoff-sumatran-rhino-ivf-program/

\section{Tech to mitigate human-wildlife conflict near Indian parks. .}

A user-friendly helpline system, Wild Seve (wildseve.org), which can be reached through a mobile phone, is helping farmers near Bandipur and Nagarhole National Parks report crop loss and predation of livestock to authorities and thus receive appropriate compensation. Such damage can otherwise lead to retaliatory killing of animals, such as elephants, whereas compensation can help foster tolerance of wildlife even in densely populated regions, such as in the 284 villages near the two Parks. The mobile technology used by the Wild Seve project speeds the compensation processes using a toll-free hotline that records the victim's voice message with details of the incident and routes it to a field coordinator, who sends a local trained responder to meet with the complainant within 24 hours. The responder photographs any damage and records statements using a mobile data collection system. 
Source: Mongabay (2018) news.mongabay. com/wildtech/2018/o8/tech-goes-back-tobasics-to-mitigate-human-wildlife-conflictnear-indian-parks/

\section{... and criminal profiling could help save tigers}

A geographical profiling tool used to catch serial criminals could help reduce the casualties of human-tiger conflict. The results of new research help explain how villagers in Sumatra coexist with tigers. If used preemptively the tool could help save tigers from poaching and retaliatory killings. This interdisciplinary research between spatial ecologists and social scientists aimed to predict where interventions to prevent human-tiger conflict could be most effective. The research mapped 13 years of human-tiger encounters to generate a geographical profile-used elsewhere to profile the locations of serial criminals - to map the risk of encounters. The technique can highlight villages where risk is very high and tolerance unusually low, and thus could help in the prioritization of interventions to prevent conflict. This will provide guidance for Fauna \& Flora International, which supports the Indonesian authorities and other incountry partners in Sumatra, helping them to prioritize interventions to reduce conflict.

Sources: Nature Communications (2018)

doi.org/10.1038/s41467-018-05983-y, \&

Science Daily (2018) sciencedaily.com/releases/2018/08/180827100428.htm

\section{EAST ASIA}

\section{China places restrictions on its domestic fishing fleet while increasing its catch in distant waters}

Despite China's most recent 5-year plan outlining ambitious fisheries management reforms designed to shift society towards sustainable development, the country's demand for seafood continues to grow. Rising incomes and seafood's position as a status symbol, coupled with public campaigns urging citizens towards healthier protein choices, have driven the rapid expansion of China's burgeoning fishing fleets. One-fifth of the global catch volume goes to satiating China's appetite for wildcaught fish, with dramatic consequences for fish stocks and critical habitats. The historically poor enforcement of domestic fisheries protections is gradually improving, but the Chinese government continues to encourage the growth of its distant water fleet with fuel subsidies. These ships, responsible for c. $15 \%$ of the global annual catch, are repeatedly observed showing blatant disregard for international regulations, threatened species protection and reporting requirements in their mission to meet rising demand at home.

Source: Hakai Magazine (2018) hakaima gazine.com/news/the-consequences-ofchinas-booming-demand-for-seafood/

\section{Hong Kong Customs and AFCD join to combat smuggling activities}

Hong Kong Customs and the Agriculture, Fisheries and Conservation Department mounted a 10-week joint operation to curb the smuggling of threatened species at airport, seaport, land boundary and railway control points during June-August 2018. They detected 118 cases, resulting in the seizure of various suspected threatened species with an estimated market value of c. USD 19 million and the arrest of 82 people. In particular, Customs seized a total of 63 tonnes of suspected threatened tree logs found in three inbound containers and seven tonnes of pangolin scales from another two. Other seized items include 85 live frogs, $317 \mathrm{~kg}$ of dried seahorses and $25 \mathrm{~kg}$ of worked ivory. Going forward, advanced equipment will be introduced to step up screening and inspection, and intelligence exchanges and regular joint operations with local, mainland and overseas law enforcement agencies will also be maintained for anti-smuggling purposes. Source: The Government of Hong Kong (2018) info.gov.hk/gia/general/201809/05/ P2018090400692.htm

\section{NORTH AMERICA}

\section{Trump's new oceans policy washes away Obama's emphasis on conservation and climate}

A new executive order from President Trump has revised U.S. oceans policy and formally revoked the 2010 oceans policy of previous President Obama. The new order stresses economic and security concerns rather than the vulnerability of the oceans, climate change or conservation. Priorities include providing economic, security and environmental benefits, promotion of lawful use of the ocean, facilitating economic growth of coastal communities, and promoting ocean industries.

Source: Science (2018) sciencemag.org/ news/2018/o6/trump-s-new-oceans- policy-washes-away-obama-s-emphasisconservation-and-climate

\section{Ghost peppers are saving US} grasslands by scaring off hungry mice Efforts to restore the native flora of the United States's grasslands have been hindered by deer mice Peromyscus maniculatus, which consistently ate newly planted seeds. Researchers attempted to deter the rodents by coating the seeds with capsaicin, the spicy active ingredient in chilli peppers. They found that dusting the seeds with chili powder reduced the number of seeds consumed by $86 \%$. However, the discovery required some trial and error to find a chilli powder that would deter the mice but not prevent the seeds from germinating and to develop a coating that would not weather away after a few months outdoors. After 4 years of laboratory and field experiments in Montana's Missoula Valley, the team found that a powder made from the Indian ghost pepper (bhut jolokia, a hybrid species) was effective. Their findings demonstrate how natural plant defense compounds can be used to aid restoration efforts.

Sources: Restoration Ecology (2018) doi.org/ 10.1111/rec.12862, \& Science (2018) science mag.org/news/2018/o8/ghost-peppers-aresaving-us-grasslands-scaring-hungry-mice

\section{Genetically engineered tree could help} save American chestnut. . .

American chestnut trees Castanea dentata once dominated forests throughout the Appalachian Mountains. But in the early 1900 s the chestnut blight, a fungal infection accidentally imported from Asia, spread rapidly after first occuring in New York City. The fungus releases oxalic acid, a toxin that kills the tree above the infection site, and by the 1950 s large trees had nearly disappeared. Now scientists are hoping to use genetically modified (GM) trees to restore the population. Thanks to an inserted wheat gene, these possess an enzyme that breaks down the oxalic acid, while producing nuts indistinguishable from those of native trees. But like GM crops and animals, GM trees are controversial, and ethical and ecological concerns are heightened because they would grow in the wild. If the regulators approve the request to release the trees, it would be the first use of a GM tree for restoring a native species in North America.

Source: Science (2018) sciencemag.org/news/ 2018/o8/save-iconic-american-chestnut-res earchers-plan-introduction-genetically-engi neered-tree 


\section{... and fears lessen that invasive fungi will extinguish Hawaii's iconic native tree}

Hawaii's red-blossomed 'ōhi'a Metrosideros polymorpha has been severely affected by an invasive fungus introduced in 2014, which has since spread across $800 \mathrm{~km}^{2}$. Dying trees on the neighbouring island of Kauai also tested positive for the fungus, fueling fears that the blight could soon wipe out entire populations. However, aerial surveys and studies on land and in the lab now suggest that some 'ōhi'a will survive. The fungi belong to two distantly related species, one of them less deadly. In addition, some trees seem to have a native resistance to both strains, and management practices such as fencing out animals can slow the spread of the fungus. Fresh lava fields in the Puna district on Hawaii may also help the 'ōhi'a's recovery as it is always the first-and often, the only-tree to get established in such landscapes.

Source: Science (2018) sciencemag.org/ news/2018/o8/fears-lessen-invasive-fungiwill-completely-wipe-out-hawaiis-iconicnative-tree

\section{Call for citizens to help the monarch butterfly}

The population of the monarch butterfly Danaus plexippus-an iconic species that migrates 3,000 miles annually-has fallen $>80 \%$ in the last 2 decades. Climate change is imperiling the monarch's Mexican wintering grounds, extreme weather events affect millions of migrating butterflies, and pesticides poison caterpillars. Milkweed, which was once ubiquitous along roadsides and in field margins but is disappearing because of habitat destruction and widespread use of herbicides, is the caterpillars' only food source. A new project at Chicago's Field Museum now aims to help by planting milkweed in urban areas along one of the butterflies' major migration corridors. Researchers investigated potential planting sites in several cities and found 41 million milkweed plants already growing there. Local citizens are encouraged to plant more milkweed in their backyards and flower beds. Monarchs quickly adopt such new breeding sites, leaving people feel empowered and able to make a positive difference.

Source: New York Times (2018) nytimes. com/2018/o9/o3/opinion/to-save-monarchbutterfly-plant-milkweed-now.html

\section{Two whooping crane chicks released in Wisconsin. .}

Two chicks of the Endangered whooping crane Grus americana were hatched in the spring of 2018 in White Oak Conservation in Florida and released to the Horicon National Wildlife Refuge in eastern Wisconsin a few months later. Their parents had been brought from Wisconsin to Florida for breeding in 2016, and this is their first offspring. The family will probably stay together until the next breeding season in spring 2019. The whooping crane population has declined as a result of hunting, habitat destruction and collision with power lines. There are now only 700-800 whooping cranes left in North America, so the addition of these new chicks is a crucial step in securing the species' survival. This whooping crane family is part of the Eastern Migratory Population, one of two experimental release programmes that seek to protect this iconic wetland bird.

Source: WJCT (2018) news.wjct.org/post/ 2-endangered-whooping-cranes-hatchedwhite-oak-released-wisconsin-refugeparents

\section{... and more than $\mathbf{4}$ million turtles arrive in Oaxaca, Mexico}

Over 4.6 million olive ridley turtles came ashore at the Playa Escobilla and Morro Ayuta sanctuaries during the 2017-2018 nesting season. These two beaches are considered the most important for the reproduction of this species. The rise in turtle landings throughout the season is largely thanks to local conservation efforts protecting the olive ridley turtle. It represents a massive increase on the 120 ,000 nestings recorded in the 1980 os, before the 1990 ban on hunting turtles was enforced. The Oaxaca population is currently the largest in the country: the number of hatchlings reaching the water increased exponentially from 3.7 million in 2012 to 79.2 million last season. However, despite its impressive recovery, this species remains in danger of extinction, facing prominent risks, most notably from fishing nets, which recently caused the death of c. 380 individuals off the coast Barra de Colotepec.

Source: Mexico News Daily (2018) mexico newsdaily.com/news/more-than-4-millionturtles-arrived-last-year/

\section{CENTRAL AMERICA AND} CARIBBEAN

\section{Environmental activist Berta Cáceres' alleged murderers go on trial}

Berta Cáceres, a human rights and environmental activist in Honduras, was a prominent coordinator of the Council of Popular and Indigenous Organizations of Honduras. For years she fought against the construction of a hydroelectric power plant on the Gualcarque River, which would have severely altered fragile ecosystems and the home of the Lenca people. Only a year after being awarded the Goldman Environmental Prize for her work, Cáceres was killed in her home in 2016 by several armed men. The trial of eight suspects is now underway, monitored by a commission of representatives of 17 international and national NGOs, as well as human rights experts. The trial will probably be hampered by repeated delays and irregularities during its preparation, including stolen investigation files and several witnesses not having been allowed to testify. Whether the court will conduct the proceedings in a transparent manner remains to be seen. Source: Deutsche Welle (2018) dw.com/en/ honduras-environmental-activist-bertacaceres-alleged-murderers-go-on-trial/ a-455 03215

\section{Rainforest food webs collapsing as climate change wipes out arthropods}

Researchers have compared arthropod biomass in Puerto Rico's Luquillo rainforest with data taken during the 1970 s and found that biomass has fallen dramatically: using the same study area and methods employed in 1976, scientists discovered that the dry weight biomass of arthropods captured in sweep samples had declined 4-8 times, and $30-60$ times in sticky traps. Lizards, frogs and birds that rely on arthropods for food have experienced parallel declines over the same time period. Forest temperatures have risen by $2.0^{\circ} \mathrm{C}$ over the last 30 years, and the study indicates that climate warming is the driving force behind this decline. Given their abundance, diversity, and central roles as herbivores, pollinators, predators and prey, the response of arthropods to climate change is of concern, with the collapse of the forest's food web being a possible consequence.

Source: PNAS (2018) doi.org/10.1073/pnas. 1722477115

SOUTH AMERICA

\section{Scientists satellite tag river dolphins in Peru for the first time}

Although it is an iconic Amazonian species, little is known about the behaviour and population status of the pink river dolphin Inia geoffrensis in Peru. Concerned about increasing pressures from pollution, 
development and bycatch, conservationists have attached satellite tags to the dolphins, enabling them to track the animals' movements. The team, led by WWF and local partners as part of a regional initiative, took blood and tissue samples and affixed satellite tags to the dolphins, to provide data on habitat use. Four were tagged in Pacaya Samiria National Reserve, one of Peru's first Ramsar sites, and a further four were tagged outside the protected area to allow for investigation into changes in dolphins' behaviour when more directly exposed to human pressures. As an indicator species, improved understanding of the status of river dolphins will help to inform the conservation of the freshwater ecosystems in which they live.

Source: WWF (2018) panda.org/wwf_news/ ?335390\%2FRiver-dolphins-in-Peru-satellitetagged-for-first-time

\section{Valenzuela marsh in danger}

The Valenzuela marsh, located in the Argentinian province of Corrientes, is in danger from dredging works and deforestation. The fertile environment is home to a number of globally threatened species. Conservationists and the local community worry that these efforts to reduce flooding are threatening vital habitat and the wildlife that depend on it. Scientists have warned that the dredging work will simply be a short-term, ineffective solution, because it could actually increase flooding in the coming years by damaging the mangrove forests in the area, which naturally regulate water levels and purity. BirdLife International is raising awareness of what is happening with the marsh. Through partner organization Aves Argentinas they have been supporting members of local groups as they call for a thorough investigation of the decision making process that led to the dredging and clearing, as well as an examination of exactly how much environmental damage these actions will cause.

Source: BirdLife International (2018) bird life.org/worldwide/news/vital-argentinanmarshlands-under-threat-dredging-clearing

\section{PACIFIC}

\section{Breakthrough as New Caledonia votes to protect coral reef}

New Caledonia has agreed to stricter protection around a huge swathe of some of the world's last near-pristine coral reefs, in a move conservationists hailed as a major breakthrough. The Pacific nation, a French overseas territory, is home to some of the world's healthiest reefs, boasting a rich array of wildlife, including 2.5 million seabirds and $>9,300$ marine species such as dugongs and nesting green sea turtles, many of which thrive in and around remote zones off the island nation's coast. After years of work, the New Caledonia government voted to set up marine protected areas surrounding the reefs, and to strengthen an existing protected area around Entrecasteaux, which is already a UNESCO world heritage site. The move will safeguard $28,000 \mathrm{~km}^{2}$ of waters from commercial and industrial fishing and other exploitation, helping conserve habitats and allow marine life to feed and reproduce undisturbed. Source: The Guardian (2018) theguardian. com/environment/2018/aug/14/breakthroughas-new-caledonia-votes-to-protect-coral-reef

\section{Rare tree kangaroo reappears after vanishing for $\mathbf{9 0}$ years}

The Wondiwoi tree kangaroo Dendrolagus mayri from the montane forests of New Guinea had not been reported since its first sighting by western scientists in 1928 , so was assumed extinct. Now it has been photographed for the first time, by an amateur botanist from the UK, who led an expedition to find the rare species in July 2018. Tree kangaroos are remarkably cryptic, remaining hidden in the high canopy of dense bamboo forest at altitudes above $1,500 \mathrm{~m}$. Scientists are planning to collect dung or tissue from this rare species, to extract DNA and compare it to genetic material from the pelt of the animal collected in 1928. Many tree kangaroos are declining because of overhunting, logging, palm oil plantations and mining.

Source: National Geographic (2018) nationalgeographic.com/animals/2018/o9/ rare-wondiwoi-tree-kangaroo-discoveredmammals-animals/

\section{AUSTRALIAVANTARCTICA NEW ZEALAND}

\section{World's largest king penguin colony suffers $\mathbf{8 8 \%}$ losses}

Thirty-five years after the last estimates of Aptenodytes patagonicus numbers on Île aux Cochons identified it as the largest king penguin colony in the world, with some 500,000 breeding pairs, recent surveys show just 60,000 pairs remain, a decline of $88 \%$. A team of scientists investigated the changing population of the island colony in the Crozet archipelago, in the southern Indian Ocean, by comparing aerial photography and satellite imaging spanning several years during 1962-2017. Their research exposed a dramatic reduction in numbers and explored potential drivers for this decline. These include climate change, competition for resources, relocation, and disease, although the authors struggled to identify any single cause that could lead to such large-scale losses and limited signs of recovery. The study stresses the need for a more thorough investigation, as should this count prove accurate, it represents a significant set-back to the global king penguin population.

Sources: Antarctic Science (2018) doi.org/10. 1017/So954102018000226, \& NY Times (2018) nytimes.com/2018/07/31/science/king-pengu in-decline-antarctica.html

\section{New Zealand to ban plastic bags}

New Zealand's government announced that they will be banning single-use plastic bags over the course of 2019. New Zealand retailers have been given 6 months to stop providing lightweight plastic bags or else face fines of up to NZD 100,000 (GBP 51,000). Prime minister Jacinda Ardern has announced the ban, to better look after the nations' environment and safeguard its clean, green reputation. Ardern stated the petition supporting the ban signed by 65,000 people showed a clear interest in taking action on this problem. New Zealand has one of the highest rates of urban waste production per capita in the developed world, with 750 million plastic shopping bags, c. 154 per person, used each year. Both of New Zealand's major supermarket chains and several large retailers in the country have said they will eliminate single-use bags by the end of 2018.

Source: The Guardian (2018) theguardian. com/world/2018/aug/10/jacinda-ardernsays-new-zealand-will-ban-plastic-bags

All internet addresses were up to date at time of writing. Note that in the online version of this document (at journals. cambridge.org/orx) all links are live and can thus be used to navigate directly to the cited sources. The Briefly section in this issue was written and compiled by Emma Muench, Julia Hochbach and Martin Fisher, with additional contributions from Annkathrin Sharp and Jessica Haskell. Contributions from authoritative published sources (including web sites) are always welcome. Please send contributions by e-mail to oryx@fauna-flora.org. 